УДК 619:614.449.57:591.465.11:619:576.895.1

(C) 2015

Юськів І. Д., доктор ветеринарних наук

Львівський національний університет ветеринарної медицини та біотехнологій імені С. 3. Гжицького

Мельничук В. В., асистент

Полтавська державна аграрна академія

\title{
ЕФЕКТИВНІСТЬ ВИКОРИСТАННЯ РІЗНИХ ТЕСТ-КУЛЬТУР ЯЕЦЬ ГЕЛЬМІНТІВ ЩОДО ВСТАНОВЛЕННЯ ДЕЗІНВАЗІЙНИХ ВЛАСТИВОСТЕЙ ХІМІЧНИХ ЗАСОБІВ
}

\section{Рецензент - доктор ветеринарних наук А. А. Замазій}

\begin{abstract}
Проведено порівняльну ефективність використання тест-культур яєиь Ascaris suum $i$ Trichuris suis, виділених з різних субстратів (з гонад самок гельмінтів та з фекалій хворих свиней), у процесі визначення дезінвазійних властивостей хімічних засобів «Бі-дез» та «Бровадез-плюс». Встановлено, щчо найбільш стійкими до дії досліджуваних хімічних засобів виявилися яйия T. suis тест-культури, отриманої з фекалій хворих свиней. Зокрема, дезінвазійні хімічні засоби у $2 \%$ кониентрації та експозищї 60 хв. призводили до загибелі 68,75-71,85\% яєиь Trichuris suis, виділених з фекалій хворих свиней, та 82,60-89,13\%виділених з гонад самок гельмінтів. Разом з тим, дезінвазійні хімічні засоби $100 \%$ згубно діяли на послідовні стадї розвитку яєцьь Ascaris suит.
\end{abstract}

Ключові слова: яйия, Trichuris suis, Ascaris suит, дезінвазійна ефективність, тест-культура, хімічні засоби.

Постановка проблеми. Загальні принципи боротьби 3 гельмінтозами свиней включають комплекс протигельмінтозних заходів, одним 3 яких є дезінвазія приміщень, вигулів і обладнання. У виробничих умовах свинарських господарств промислового типу дезінвазія $є$ заключною ланкою спеціальних заходів протигельмінтозного комплексу і складовою частиною технології виробництва тваринницької продукції. Дезінвазія об'єктів зовнішнього середовища не завжди є ефективною проти зародків паразитичних червів, тому ведеться пошук ефективних хімічних засобів із низькою концентрацією, кратністю застосування та експозицією.

Аналіз основних досліджень і публікацій, у яких започатковано розв'язання проблеми. За даними літератури $[5,12]$, перед тим як запропонувати виробництву хімічний засіб, що володіє дезінвазійними властивостями, його випробовують у лабораторних умовах на тесткультурах яєць, личинках, ооцистах паразитів та на різних етапах ембріонального розвитку. Згідно 3 дослідженнями А. А. Черепанова серед яєць гельмінтів еталоном стійкості й, відповідно, тест-об'єктом для вивчення овоцидної ефективності дезінвазійних засобів є визначення життєздатності яєць Ascaris suum (Goeze, 1782) методом культивування. Матеріалом для позитивного контролю за овоцидною ефективністю дезінвазійних засобів є яйця збудників Toxocara canis, Toxascaris leonine, Ascaridia galli, Parascaris equorum $[11,12]$.

Тому важливо проводити попередне встановлення овоцидної дії перспективних хімічних речовин in vitro на різних тест-культурах яєць 3 метою встановлення ступеня прояву знезаражуючої активності та розробки у майбутньому ефективних, екологічно раціональних дезінвазійних засобів [2, 3, 5, 6, 8-10].

У зв'язку з цим, робота в даному напрямі $є$ актуальною, адже дає змогу встановити стійкість тест-культури яєць до хімічних засобів за певного гельмінтозу.

Мета дослідження - порівняти ефективність використання різних тест-культур яєць щодо визначення дезінвазійних властивостей хімічних засобів за нематодозів свиней.

У завдання досліджень входило встановити дезінвазійні властивості хімічних засобів «Бідез» та «Бровадез-плюс» відносно тест-культур незрілих яєць Ascaris suum і Trichuris suis, виділених з різних субстратів.

Матеріал і методи досліджень. Дослідження проводилися упродовж 2014-2015 років на базі наукової лабораторії кафедри паразитології та ветеринарно-санітарної експертизи факультету ветеринарної медицини Полтавської державної аграрної академії.

Визначення виду гельмінтів, їх яєць проводили за морфологічними особливостями їхньої будови, а також за даними довідникових видань літератури [1]. Отриманий матеріал досліджували методами флотації з розчином нітрату амонію та за Фюллеборном [4]. 
ВЕТЕРИНАРНА МЕДИЦИНА

Дезінвазійна ефективність хімічних засобів «Бі-дез» та «Бровадез-плюс» щодо різних тест-культур за експозиції 60 хв.

\begin{tabular}{|c|c|c|c|c|c|}
\hline \multirow{2}{*}{$\begin{array}{c}\text { Хімічні } \\
\text { засоби }\end{array}$} & \multirow{3}{*}{ Концентрація } & \multicolumn{4}{|c|}{ ДЕ, \% } \\
\cline { 3 - 6 } & & \multicolumn{3}{|c|}{ Ascaris suum } & \multicolumn{2}{|c|}{ Trichuris suis } \\
\cline { 3 - 6 } & & маточні & фекальні & маточні & фекальні \\
\cline { 3 - 6 } & $1 \%$ & 97,72 & 95,74 & 79,34 & 59,37 \\
\hline \multirow{3}{*}{ «Бі-дез» } & $1,5 \%$ & 100 & 97,87 & 82,60 & 67,70 \\
\hline & $2 \%$ & 100 & 100 & 89,13 & 71,85 \\
\hline & $1 \%$ & 85,22 & 87,23 & 77,17 & 48,98 \\
\hline & $1,5 \%$ & 92,04 & 84,04 & 78,26 & 60,41 \\
\hline & $2 \%$ & 100 & 100 & 82,60 & 68,75 \\
\hline
\end{tabular}

Експериментальне визначення дезінвазійних властивостей засобів «Бровадез-плюс» та «Бідез» НВФ «Бровафарма» (Україна) проводили на незрілих яйцях Ascaris suum і Trichuris suis методом культивування. Життєздатність яєць паразитів оцінювали стандартизованими методами [7].

Яйця Ascaris suum i Trichuris suis отримували безпосередньо з кінцевих відділів матки кількох самок гельмінтів (Ям) та виділяли з фекалій хворих свиней (Яф).

Отриману суміш яєць змивали дистильованою водою в окремі чашки Петрі. На кожен хімічний засіб для кожної культури яєць гельмінтів було підготовлено по три чашки з культурою яєць із різною концентрацією («Бровадез-плюс» та «Бідез» - $1 \%, 1,5 \%, 2$ \% відповідно) та експозицією 60 хв. До попередньо підготовленої суміші яєць Ascaris suum i Trichuris suis додавали такий самий об'єм розчину препарату певної концентрації. Після відповідної експозиції суміш яєць чотириразово відмивали в дистильованій воді. Чашки Петрі із сумішшю яєць гельмінтів поміщали в термостат за температури $27^{\circ} \mathrm{C}$ і упродовж 45 діб вели спостереження. Через кожні п'ять діб культури розглядали під мікроскопом (х 80, х 100). Відзначали послідовні стадії розвитку яєць гельмінтів, враховуючи зміни оболонки, деформацію зародків та стан розвитку личинок або їх пошкодження. Було підготовлено чотири контрольні та 24 дослідні чашки Петрі.

Оцінку дезінвазійної ефективності хімічних засобів проводили за показниками: високий рівень ефективності - 90-100\%, задовільний - 60$90 \%$, незадовільний - до $60 \%$.

Результати досліджень. 3 наведених у таблиці даних видно, що найбільш стійкими до дії хімічних засобів «Бі-дез» та «Бровадез-плюс» виявилися яйця Trichuris suis, отримані 3 фекалій хворих свиней.

Зокрема, хімічні засоби у $1 \%$ концентрації призводили до загибелі 48,98-59,37 \% яєць трихурисів, виділених з фекалій хворих свиней, що на 17,85-19,97\% менше, ніж за використання в якості тест-культури яєць трихурисів, виділених 3 гонад самок гельмінтів та на 36,37-38,25\% - за використання яєць аскарисів, виділених 3 фекалій хворих свиней, а також на 36,24-38,35 \% - яєць аскарисів, виділених з гонад самок гельмінтів.

Хімічні засоби у 1,5\% концентрації призводили до загибелі 60,41-67,70\% Яф трихурисів, що на 14,9-17,85 \% менше, ніж за використання Ям трихурисів; на 23,63-30,17 \% - Яф аскарисів; на 31,63-32,3\% - Ям аскарисів.

Дослідження показали, що хімічні засоби у $2 \%$ концентрації призводили до загибелі $68,75-$ 71,85 \% яєць трихурисів, виділених із фекалій хворих свиней, що на 13,85-17,28 \% менше, ніж за використання яєць трихурисів, виділених 3 гонад самок гельмінтів та на 28,15-31,25\% - ніж за використання культури яєць аскарисів, отриманої як з кінцевих відділів маток гельмінтів, так і $з$ фекалій хворих свиней.

Отримані результати свідчать, що дезінвазійні засоби «Бі-дез» та «Бровадез-плюс» за всіх концентрацій мають високий рівень дезінвазійної ефективності (ДЕ 85,22-100\%) щодо тесткультури яєць Ascaris suum (Яф та Ям). Разом 3 тим, хімічні засоби були менш ефективними стосовно тест-культури яєць Trichuris suis і мали задовільний рівень дезінвазійної ефективності (ДЕ $=60,41-89,13 \%)$.

\section{Висновки:}

1. Встановлено, що тест-культури яєць аскарисів та трихурисів, отриманих з фекалій хворих свиней, $є$ більш стійкими до дії засобів «Бі-дез» та «Бровадез-плюс» порівняно з тест-культурами яєць, отриманих з гонад самок гельмінтів.

2. Експериментально доведено, що яйця Trichuris suis виявилися більш стійкими, ніж яйця Ascaris suum в якості тест-культури щодо ви- 


\section{ВЕТЕРИНАРНА МЕДИЦИНА}

значення дезінвазійних властивостей хімічних засобів.

3. Запропоновані хімічні засоби «Бі-дез» та «Бровадез-плюс» у 2 \% концентраціях за експо-

\section{БІБЛІОГРАФІЯ}

1. Галат В. Ф. Морфологія гельмінтів тварин : атлас / В. Ф. Галат, В. О. Свстаф'єва, М. В. Галат. Полтава : ВАТ «Видавництво Полтава», 2009. $100 \mathrm{c}$.

2. Довгій Ю. Ю. Нематодоцидні властивості дезінфектантів вітчизняного виробництва / Ю. Ю. Довгій, Д. В. Фещенко, О.І.Сергієнко // Ветеринарна медицина України. - 2010. - №3. C. $36-38$.

3. Згозинская О. А. Сравнение дезинвазионной эффективности различных дезинфектантов при нематодозах лошадей / О. А. Згозинская // Современные аспекты патогенеза, клиники, диагностики, лечения и профилактики паразитарных заболеваний : VIII республ. науч-практ. конф. 2728 сентября 2012 г. : матер. докл. - Витебск, 2012. - C. 100-101.

4. Котельников $Г$. А. Гельминтологические исследования животных и окружающей среды / Г. А. Котельников. - М. : Колос, 1984. - 128 с.

5. Методичні рекомендації щодо випробування і застосування засобів дезінфекції та дезінвазії у ветеринарній медицині / [Завгородній А. I., Павленко С. В., Луценко Л. І. та ін.]. - Х. : ННЦ Ін-т експерим. і клініч. вет. медицини, 2005. $17 \mathrm{c}$.

6. Наумычева М. И. Стойкость яиц нематод к зиції 60 хв. проявили високий рівень дезінвазійної ефективності (100\%) щодо тест-культури яєць Ascaris suum та задовільний рівень $(68,75-$ 89,13 \%) щодо тест-культури яєць Trichuris suis.

химическим веществам и другим физическим факторам : дисс. на соиск. уч. степени к. вет. н. / М. И. Наумычева. - М., 1954. - 111 с.

7. Пішак В. П. Лабораторна діагностика паразитарних інвазій / В. П. Пішак, Р. С. Булик, O. I. Захарчук. - Чернівці : Медуніверситет, 2007. - 284 c.

8. Пригодін А. Боротьба з гельмінтозами тварин / А.Пригодін // Ветеринарна медицина України. - 2002. - №4. - С. 36.

9. Трушин И. Н. Химические средства для дезинвазии свинарников / И. Н. Трушин // Ветеринария. - №6. - 1963. - С. 76-78.

10. Фотіна Г. А. Токсикологічна оцінка та дезінфекційна ефективність препарату «Бровадезплюс» : автореф. дис. на здобуття наук. ступеня к. вет. н. : спец. 16.00.04 «Ветеринарна фармакологія та токсикологія» / Г.А. Фотіна. - Львів, 2008. - 20 c.

11. Черепанов A. A. Дезинвазия животноводческих помещений: состояние вопроса и перспективы исследований / А. А. Черепанов, П. К. Кумбов // Тр. ВИГИС. - М., 1997. - Т. 33. - С. 164-184.

12. Черепанов A. A. Методические рекомендации по испытанию и применению средств дезинвазии в ветеринарии / А. А. Черепанов. - М., 1999. - 17 c. 